\title{
The Relations between the State and the University in Ethiopia: The Case of Addis Ababa University Since 1950
}

\section{Gashaw Shaw*}

Department of Social Science, Addis Ababa University College, Ethiopia

\begin{abstract}
This study examines the relations between the University and State (political power) with a particular reference of Addis Ababa University under the three successive regimes. Methodologically, the study employed qualitative methodological approach and case study research design. Accordingly, the study has used both primary and secondary sources of data in which primary data were gathered through key informant interviews while secondary data were collected from books, journal articles, reports and institutional website sources. In view of that, the study employed qualitative methods of data analysis particularly document analysis and descriptive narrative. The finding of the study shows that there exist a complex, even sometimes a destructive, and in certain cases a hostile relation between the University (Addis Ababa University) and the State which is an element of continuity. The study identifies that the university-State relation under the three regimes have followed a top-down approach with a different degree. Though each supplies the other, their relations remain suspicious. On the one hand, the university contributes to the socio-economic and political development of the State by producing manpower while the State provides fund. On the other hand, the university, throughout the three regimes, has always been a source of resistance, protest, and even revolution and armed struggle. This is common to all the three regimes. As a response, all the three regimes have responded violently though with different. The study has come up with the reasons that cause the relations between the university and the State uncertain and suspicious. This includes absence of institutional autonomy and academic freedom, State interference, State dominance of the administration of university and the political orientation of each regime. This study, therefore, calls that unless the top down model of relations between the university and the State is not revised, and institutional autonomy granted, it would be the norm to have tense relations between them. Thus, it would be paramount to have a culture of interdependence in their future relations.
\end{abstract}

Keywords: Education; Arts; Sociology

\section{Introduction}

The relations between the State and the University throughout the world are a highly complex issue. In some countries, the relations between the State and the University can be identified as a centralised (top-down) system where the State plays a major role in defining the activities of the University, while in other countries the relationship is a de-centralised (bottom-up) system where universities themselves play a central role in determining their own activities.

Whatever relations they have, it is true that the university and the State must have a mutual relation in all aspects. However, this is not the case in Africa as elsewhere in developing countries where Higher education institutions are financed, supplied and dominated by the State $[1,2]$. It is obvious that there has been a destructive relationship between African States and universities and, intellectuals and students, in this regard, have been struggling and paid a heavy price for academic freedom, institutional autonomy and freedom of expression [1]. Thus, Ethiopia is not exceptional rather there exist a complex and even in certain cases a hostile relation between University and the State. This is particularly true in case of Addis Ababa University, one of the oldest and foremost universities in the country. The objective of this study is, therefore, to examine the relations between the University and State (political power) with a particular reference of Addis Ababa University in the three successive regimes. To this end, primary sources such as key informant interviews and secondary sources such as Books, Journal Articles, Reports and Website source are utilized.

To this end, the paper has three sections. The first section revealed the relations between Addis Ababa University and the State in the three successive regimes. The second and the third part dealt with the challenges and prospects of the relation between the State and the university. Finally, the paper winduped with conclusion.

\section{The State and University in Ethiopia: A Historical Perspective}

The State and the university (Addis Ababa University) have complex relations in the three successive regimes namely the imperial regime from the 1950's onwards, the military Derg regime and the current Ethiopian people's Revolutionary democratic Front (EPRDF) regime (Hussein, 2006). The role of Addis Ababa University is teaching, research and community service. The university has been undertaking its responsibility since its establishment. The university has six stakeholders such as academic staff, administrative staff, students, State, and private sectors and the community (Ibid). Therefore, the relations of Addis Ababa University and State meant that the relationship between these six pillars also called the university community and the State. Accordingly, the paper examines university (university community)_State relations vis-à-vis academic freedom and autonomy. Thus, the following section dealt with the relationship between Addis Ababa University and the State in the three successive regimes.

*Corresponding author: Gashaw Shaw, Department of Social Science, Addis Ababa University College, Ethiopia, Tel+ 251-111-239650; E-mail: mugashawbzu@gmail.com

Received December 12, 2017; Accepted January 10, 2018; Published January 17,2018

Citation: Shaw G (2018) The Relations between the State and the University in Ethiopia: The Case of Addis Ababa University Since 1950. Arts Social Sci J 9: 327. doi: 10.4172/2151-6200.1000327

Copyright: () 2018 Shaw G. This is an open-access article distributed under the terms of the Creative Commons Attribution License, which permits unrestricted use, distribution, and reproduction in any medium, provided the original author and source are credited. 


\section{State and university during the imperial regime}

'The University College of Addis Ababa'" was founded in 1950 with the blessing of the imperial government, then renamed 'Haile Selassie I University' in 1962 and became 'Addis Ababa University' in 1975 [3-5]. The establishment of Addis Ababa University (AAU), formerly 'Haile Sellassie I University' marks the most recent step in the development of modern higher education in the country.

The first decade since the establishment of the university in 1950 as a university college there had been amicable relations between the university community (academic staff, administrative staff and students) and the imperial government. In the early of 1950's the imperial government also granted autonomy to the university by a charter. This period is a period of expansion for AAU [6]. Fisseha argues that "by the end of the first decade of its existence, Addis Ababa University had grown to be one of the largest universities in sub-Saharan Africa in both enrolment and diversity of educational programs" [7]. This is the only period (a decade) in the history of Addis Ababa University where the university community (mainly academic staff and students) were either politically neutral or apathetic or both inactive and neutral.

Since the 1960's to the end of the imperial regime, the UniversityState relationship was characterized as confrontation in which university students protest the regime and demand a reform [8]. However, the regime was reluctant to make a reform and respond the question of the students and consequently the students eagerly opposed the regime and even call the end of the imperial regime. Thus, the university has become the home of protestors [5].

In one hand, this period (from 1960-1970's) was a period which heralded the rise of student political activism and it was also a period of demonstrations and active mobilization of forces against the regime [9]. On the other hand, government forces had responded violently and targeted the academic community particularly the students (the administrative staff were mostly pro-government). The demonstrators have become the victims of human rights violations. This indicates that the university-State relationship from the 1960's onwards was a hostile relation particularly between students and the imperial government.

Despite the hostile relation between the students of the university and the imperial government, there was academic freedom ${ }^{2}$ (at least to a lesser extent) as compared to the military-Derg and the current EPRDF regimes. Academic freedom, although not a fundamental human right, is a basic university right. Academic freedom is the freedom of teachers, students, and academic institutions to pursue knowledge [10]. Academic freedom implies the freedom of academic staff members from outside interference with regard to the selection of research topics and the publication of the results of the research in question. Without academic freedom, universities will never fully accomplish their primary tasks of transmitting and discovering truth.

In this regard, there was academic freedom during the imperial period than during the Derg and EPRDF regimes. During the imperial regime there was no fear on the parts of students as long as their actions were in the campus. This created conducive environment of debate and dialogue and encouraged vivacious discussions and in turn enables students to be a critical-thinker. Thus, Students of the early 1960s and

${ }^{1}$ Addis Ababa University College was the first modern institution of higher education in Ethiopia and initially the university college was run by French-Canadian Jesuits.

${ }^{2}$ In 1954 the imperial government enacted a charter which granted autonomy to the university but later suspended when the military regime came to power in post 1974. mid-1970s were critical-thinkers and they also challenged the system. This is due to the existence of academic freedom. The reason behind the existence of academic freedom in those days is not an easy question. It may depend on different grounds than the imperial blessing for the existence of academic freedom in the university. Why there was academic freedom during the imperial period? The first reason, in this regard, can be the personality and leadership quality of the administrative staff of the university particularly university presidents. The administrators mainly the presidents of the university have used their position to maintain a good relationship with the imperial government and they have also a good educational background. For instance, the first three Ethiopian Presidents of Haile Selassie I University between the 1950s and mid-1970s were educated in the West (mainly in the United States and UK) and have had exposure to the administration of education. Second, the presidents of the university have used their affiliation with the Emperor to protect academic freedom. A good example in this case would be Lij Kasa Wolde Mariam, the first president of Haile Selassie I University (1962-69), who was member of the imperial family. He has used his proximity and relationship with the Emperor to protect academic freedom. In general the administrative officials had the enlightenment, foresight and the strong personal character to maintain academic freedom and the campuses' integrity from political interference.

Despite the existence of academic freedom, even to a lesser extent, during the imperial regime, the academic community mainly the students had opposed the regime and demand a reform. The State (political authorities) and university relation in those days can be judged as a period of paternalism. Thus, the period is a period of paternalism and imperial patronage of higher education in the country. Therefore, the relationship between the university and the State at this period was a patron-client relationship.

\section{State and university during the Derg regime}

In the aftermath of the downfall of the imperial regime, Addis Ababa University was in a troubled place, forced to design the curriculum in conformity with the State ideology ${ }^{3}$, the philosophy of Marxist-Leninist ideology $[4,5]$. The relationship between the Addis Ababa University and the State after the fall of the imperial regime was both complex and destructive and students continued a bitter struggle for freedom of expression, academic freedom and university autonomy. The student movement was one of a dominant factor for both the fall and coming power of Haile Selassie's regime and the military Derg regime respectively. Thus, the new government had a good justification to dominate and control the university.

Initially Student support for the revolutionary changes gave the new regime the time to consolidate its power. However, it was very quickly that the students began to challenge the military regime (The Derg). They demanded the return of the soldiers to their camps and called for the establishment of a people's government [8]. Unfortunately, this led to strained and bitter relations between the university communities particularly the students and the government. In this regard, the

${ }^{3}$ When the Derg Regime came to power in 1974, they accepted socialism as the fundamental political philosophy of the government. Thus, Marxist-Leninist philosophy has become the guiding ideology of the State. As a result, the curriculum during this period was highly politicized and teachers are required to develop the curriculum based on the philosophy of socialism and education system of socialist countries

See Alemayehu and Jon Lasser (2012) Education in Ethiopia: Past, Present and Future Prospects, African Nebula, 5.

Adejumobi, Saheed A (2007) The History of Ethiopia. London: Greenwood Press 
'Zemecha', 'Red Terror', land redistribution policy, the process in the creation of People's Democratic Republic of Ethiopia (PDRE) constitution, and curriculum were areas of dispute which eroded the relations between the university community and the State.

First, the university and the State relations can be viewed as a centralised (top to down model). This is true with regard to curriculum. In the aftermath of 1974, the ideology of the State was changed and became Marxism-Leninism [5,8]. This means that the curriculum which was designed based on western experience (particularly the U.S and UK) during the imperial regime must be redesigned in accordance with Marxism-Leninism orientation. Accordingly, university teachers were engaged in an arduous task of revising the curriculum in order to bring it in line with the State ideology. In this regard one of the most difficult problems was in the department of history. The government accused members of academic staff in the History Department as being 'anti-Marxist', of not teaching the history of the masses as this related to the Ethiopian people. How to teach history caused a lot of tension among the staff, between academic staff and the State and even among student, academic staff and the State at a 'triangular' level. Thus, university-State relations were more complex and hostile in the department of history than others. Not surprisingly, in 1979 the government initiated and call for burning of "thousands of Ethiopian books", though it was stopped by the intervention of the Institute of Ethiopian Studies. This shows the authoritative relations of the State with the university. The actions of the government were against the inherent institutional rights of university's autonomy. Despite the theoretical existence of different stakeholder in curriculum designing the university community, industry and the State_the State remains the authoritative stakeholders over curriculum. Thus, the State-university relation with regard to curriculum is a top-down model.

Second, some program and action of the government was against autonomy of the university and in turn eroded the relations between the university community and the State. One of these programs was the 'Zemecha'. In the end of 1974 and early of 1975 the government announced the programme of 'Edget Behibret Zemecha', the Development through Cooperation Campaign, seemingly designed to enable students to teach the peasants in order to implement the changes brought by the revolution but widely viewed as an instrument to expel the students out of the capital because the new government was aware of the fact that they _university students_ were a critical factor in the overthrow of the Haile Sellassie I regime $[5,8,11]$. The programme of 'Zemecha' was forcefully imposed by the new government and students were obliged to take part. Consequently, the university was closed for two years. This meant that university autonomy during the time of Derg was in question. University autonomy is a crucial right of higher educational institutions. It is the right of a university to be free from State interference with regard to its internal affairs. Without institutional autonomy, it is impossible for a university to fully accomplish their 'raison d'être' such as teaching, research and community service. In this regard, Addis Ababa University was closed for two valid years due to the programme of the so-called 'Zemecha'. This meant that the State interfere in the internal affairs of the university and consequently forced the university to ended up its official business, teaching. Thus, the action of the State is simply arresting the university.

The university was re-opened in in the autumn of 1976, after two years of closure due to the 'Zemecha' $[5,12]$. The university community particularly the academic staff faced numerous difficulties on how to meet the challenges of teaching in the aftermath of the re-opening of the university after the 'zemecha' and how and what to teach under the new conditions remains the big challenge. Since the revolution, the university was in a difficult situation and relation with the new dictatorial government and the most horrible period was during the 'Red terror'. The Military dictatorial regime had killed thousands of intellectuals and students throughout the year 1977 and 1978 [13]. It was targeted the university students at large. Thus, University StudentsState relations were hostile.

In 1984 (the initiation was trace back to 1978) the government announced a resettlement and 'villagaziation' program [11,14]. The entire university community of Addis Ababa university_ Students and academic staff, and supportive staff_ were all ordered by the government to go and aid the great "resettlement" of the Northerners. This was not voluntary rather forced even it was against the will of the university community particularly the academic staff and students while the administrative staff (leaders of the university) had found it to be in their interest since they had no position to refuse it as they were both members and instruments of the new, government-initiated Workers' Party of Ethiopia. This highly eroded even discourage the morals of the intellectuals and even some call the president in chief Mengistu's speech of "everything is possible" as discouraging.

All of the above programs and actions of the government indicates that the university community particularly students and academics staff had a hostile relation with the regime. The University academic staff was required to incorporate Marxist-Leninist literature into the curriculum and also forced to attend weekly political discussion forums. No question that there was no academic freedom and institutional autonomy. The university academic staff and students had a hostile relation with the State while the administrative staff had amicable relation since they were affiliated of the ruling government.

Consequently, all of these situations led to brain drain which was not seen before the coming power of the military regime via revolution in $1974[15,16]$. Bento argues that "brain drain became a major problem in Ethiopia only after 1974, as a consequence of the political persecution and 'Red Terror' of the Derg government" [17]. Although both pull and push factors contributed for brain drain, the push factor is one of the underlying causes for brain drain during the military dictatorial regime. Absence of a friendly relation between the university and the State, centralized (top-down) and authoritative relation of State with the University, inexistence of academic freedom and institutional autonomy, targeting the young educated, absence of political freedom were the push factors that oblige the intellectuals to leave their mother land.

Even though brain drain is not unique to Ethiopia, brain drain is neither seen nor occurred during the imperial regime. Research indicates that prior to the 1974 revolution almost all Ethiopians who attended university in the country remained at work in their country and the vast majority of those who studied overseas returned to Ethiopia [18]. Thus, the major turning point for the emigration of Ethiopian intellectuals was the period of the Derg regime. A study shows that the number is increased with the case of Addis Ababa University. For instance, out of 135 academic staff who was teaching at AAU in the early 1970s, almost half of them had left Ethiopia by the mid-1980s [17]. Thus, we found that the number of Ethiopian intellectual emigrants have been increased since the coming power of Derg and continued with an alarming rate even under the current EPRDF Regime. Although there are other factors, the most contributing factors for brain drain in both Derg and EPRDF regime are absence of institutional autonomy (university's independence), academic freedom, and politicized education and centralized State-university relations at large. 
In general, the University State relations during the Derg regime were a destructive and one of a hostile if not friendly. Since the revolution in 1974, the University students and State relation is almost that of confrontation than a friendly one. Since the very day of the seizure control of power by the military council, Derg, students have been eagerly struggling for academic freedom and institutional autonomy. Unfortunately, the military government was neither willing nor abandoning the existence of the two inherent rights of the university, academic freedom and institutional autonomy. Academic staff_ Government relation is also not different form that of students State relations. Unlike the two university community (students and academic staff) which had hostile relation with the State, the university leaders had amicable relationship with the government which can be viewed as patron -client relationship between them. The president and vice president of the university were appointed by the regime from members of the Workers' Party of Ethiopia, following its creation in 1984. Thus, loyal individuals than qualified professionals, political affiliated than independent intellectuals, were eligible to the office of president and vice-president. Thus, a patron-client relationship can best explain the university-State relation in terms of Administrative staff while the Student_State and academic staff_State relations were unstable and hostile.

\section{State and university under the current EPRDF regime}

The current ruling government of the State, led by the Ethiopian People's Revolutionary Democratic Front (EPRDF), came to power in 1991 with an atmosphere of great hope, in the immediate fall of the People's Democratic Republic of Ethiopia (PDRE) government led by President Mengistu Hailemariam. In the early period following the overthrow of the military dictatorship, the relations between the University and the new government were characterised by a great deal of uncertainty and contradiction. Though the new government promised to restore university autonomy which was granted and suspended by the imperial and military Derg regimes respectively, university autonomy remains in question till 2003. Hussein argues that two factors contributed for the cool relations between the university and the State in the early period of 1990's. First, there was a space and scope for mutual understanding between some of the academic staff of the University and the political leadership [4]. However, the new government suspected that the university had identified itself close to the Derg; this suspicion may be due to the fact that some members of the university were members of the Workers Party of Ethiopia. Thus, the new government viewed the university as potential disloyal to them. Second, the new government have described the University as a fortress of elitist arrogance.

Efforts has been made to normalize the relations between the State and the university through media by invoking the importance of stabilizing relation and good governance, though circumstance and situations reactivated the already incertitude relation between them. There were several student demonstrations against some aspects of the new government's ethnically-based politics. One of the most hostile relations between the university students and the State, since the coming power of EPRDF, took place on January 4, 1993 when the university students demonstrating to express their opposition to the proposed visit to Eritrea of the UN Secretary- Generatros Boutros Boutros-Ghalil prior to the referendum $[4,19]$. In a response, government forces responded forcefully and arrested large number of students. Consequently, the university was closed for more than three months.

Moreover, a large number of staff (41) was also summarily dismissed by the government_ the reason was seemed to be violation of contracts, as well as government and university policies. In the July and August 2002, a three weak capacity building workshop was given for the university academic staff. At the end of the workshop, the late Prime Minister Meles Zenawi confirmed that the government had dismissed the professors because they had made the university their 'political headquarters' (ibid). However, some source shows that the university teachers were dismissed because of their political stand $[4,19]$. This all indicates that the State has exclusive power over the university. Thus, university autonomy is inexistence, though the EPRDF regime promised to restore autonomy of the university, which was granted by the imperial regime but suspended by the Derg, in the aftermath of the downfall of Derg.

In 2001 Addis Ababa university students submitted a written petition to the university administration. Their main complaints were; they wanted independent press to publish student newspaper that the administration had blocked; independent student union without university interference; and the removal of armed and police force from the campus. However, neither the university administration nor the ministry of education responded to the students' question. Consequently, the students went on strike in the struggle for academic freedom. The strike began on April 9, 2001. One the eve of the demonstration, students had attended a public meeting (speech) led by former AAU member of academic staff Professor Berhanu Nega and Professor Mesfin Woldemariam, members of the executive committee of Ethiopian Human Rights Council. At that meeting, students expressed their commitment to stand up for their human rights and academic freedom. As a response, security forces even without authorization responded to the protests with extreme brutality. Accordingly, a number of students decided to boycott class, leading to a large-scale student strike. Professor Berhanu and Professor Mesfin were also arrested a month later, in the pretext of challenging the constitution through illegal means. Thus, the relations among the student, academic staff and the administration and the government are too complex and destructive [17].

In general, the AAU-State relation under the current ruling government can be viewed as a top-down relation where the State dominates the university in various ways [20]. The following are ways of State control over the university. First, budget dependence; all public universities are generally funded by the state. This is stated in article 62 of the Proclamation no. 650/2009 higher education proclamation; Public institutions shall be funded by the federal government or States [21]. This situation allows the government to control the university. Second, appointment of members of the board and the president; both of them are appointed by the government by examining their affiliation with the government. This enables the government to control and follow up the university. Third, prescribed strategies and reforms are given by the State to the university. Since the launch of the Growth and Transformation Plan (GTP), all public institutions are required to revise their policies and strategies in conformity with the GTP. Thus, it is another ways of control. Fourth, the '70-30' policy launched by the government is also another indicator of the top down relations of the State and the university. ' $70-30$ ' policy means that $70 \%$ of students in higher education will be assigned to fields of natural sciences and technology while the remaining $30 \%$ will go to the social sciences and humanities without considering the capacity and interest of the university. Thus, the University has no right to decide on student's admission. Fifth, despite the existence of five stakeholders of the university (State, Students, academic staff, administrative staff, private sectors and the community), the State remains the most significant 
stakeholders in all areas (Saint, 2004). The intention of the State is clearly stated in the 2009 higher education proclamation ${ }^{4}$ which allows the State to provide guidance for other stakeholders.

However, it does not mean that the relations between them are always a top-down rather a top-down model is manifested at large. Thus, there has been some progress which is to be appreciated. For instance, recently the government make structural reorganization of all public institutions [22]. The orientation it followed in implementing the reform is quite different from the top-down approach and, thus, individual institutions are given autonomy to implement their own reform. Although the government granted autonomy to the university by enacting law, in practice autonomy is a deadlock issue. Under the current government, the university lacks not only autonomy but also lacks academic freedom, theoretically the proclamation have granted the university both autonomy and academic freedom, however. For instance, around 41 academic staffs are summarily fired and some of those dismissed have been imprisoned for advocating academic freedom ${ }^{5}$ while others fled to other country and even some are died in a prison. Thus, students and academic staffs have paid a heavy priceless struggle for academic freedom and institutional autonomy [23-25].

\section{Challenges of University State Relations}

The relationship between university and State in Ethiopia as elsewhere in most African countries have been a destructive and complex in its nature. The university community have been struggling for academic freedom and institutional autonomy. The following are considered to be the constraints in the relations between AAU University and the State.

\section{The failure of the State to restore university autonomy}

University autonomy was originally granted in 1954 by the charter during the imperial period and suspended by the military dictatorial government $^{6}$. In the aftermath of the coming power of EPRDF, they promised to restore university autonomy. However, they failed to reinstitute the charter, which was cancelled by the Derg regime, to grant both administrative and financial autonomy. Research indicates that the whole problems are linked to government interference with the university administration. Thus, absence of autonomy remains the big challenge of AAU relations with the State. Though it is too late and too little, the government has granted autonomy by enacting a law in 2003 and revised in 2009.

\section{Inadequate infrastructural improvement and technological expansion}

Another area which can be regarded as a challenge for the friendly relation between the university and the State are infrastructure particularly inadequate internet access. Though significant investment has been made to build class rooms, dormitories, libraries and laboratories, the quality is in question. Although it remains illogical, some members of the university community associated the quality related problem of the investment in the university to the State failed policy. In this case, we found that there is no adequate internet

${ }^{4}$ Article 4 (6) and 24 (2) of the proclamation no. 650/2009 higher education proclamation.

See Federal Democratic Republic of Ethiopia (FDRE) (2009). Higher Education Proclamation No. 650/2009, Federal Negarit Gazeta, No. 64,17th September 2009, pp. 49765044.

${ }^{5} \mathrm{Dr}$. Taye and Professor Mesfin Woldemariam were imprisoned.

${ }^{6}$ When the university was first created, Emperor Haile Selassie granted it independence through a charter. But the Derg suspended that independence. service in the university particularly in the main campus. Thus, some students suspected that this may be the policy of the State to halt communication among students before, during and after the time of a possible demonstration and strike. This may affect the relation between them and may increase suspicion and uncertainty.

\section{Conflicts, mistrust and misunderstanding between students- academic staff, and the university administration and the government}

Another challenge is the suspicion between the students/academic staff and the university administration, and between the students/ academic staff and the government. The students/Academic staff regarded the administration as government appointed and party affiliated and therefore viewed as the eyes and ears of the government. Thus, distrust rather than trust is the hallmark characteristics between them. For a friendly relation between them conflicts and misunderstanding should be resolved by dialogue. It is paramount for all the parties concerned (the university community and the State) to resolve their dispute by negotiation.

\section{The imposition of State policy in the absence of consultation and discussion among the stakeholders of the university}

The imposition of State policy in the absence of consultation and discussion among the stakeholders of the university such as the students, academic staff, the administrative staff, supportive staff and the industry (private sector) may affect the friendly relations between the university and the State. Unilateral decision of the State over curriculum, restructuring of the university administration and evaluation performance and employment can be regarded as challenge in the relations between the university and the State.

\section{Prospects of the University-State Relations}

Without academic freedom and autonomy, it may be too difficult to assume that a certain higher education institutions are fulfilling their duties and official business. Thus, the State should refrain from interfering in the internal affairs of the university. If the State allows academic freedom and autonomy, no question that the State and the university relation would be that of interdependence than dependence.

The relations between the university and the State should be inspired by a shared sense of responsibility, transparency and accountability, and by a common objective. Both the State and the university should give priority for the public interest and one should be the arm of the others since their mission and vision is not against the public interest. Giving priority for the public interest will bring the idea of interdependent than dependence. Therefore, the relation between the university and the State should be revised in line with the idea of interdependence than dependence, democratic culture than authoritative relations, decentralized than centralized (top to down), and mutual trust and understanding than mistrust and uncertainty. Besides this, there should be a continuous and constructive dialogue based on genuine partnership between stakeholders of the university such as students, academic staff, the administration, the government, the private sector and the community at large.

\section{Conclusion}

This paper examines the relations between the University and the State in the three regimes (the imperial, the Derg and the EPRDF) by taking Addis Ababa University as a case. Accordingly, the paper identifies that the university-State relation in the three regimes have 
Citation: Shaw G (2018) The Relations between the State and the University in Ethiopia: The Case of Addis Ababa University Since 1950. Arts Social Sci J 9: 327. doi: 10.4172/2151-6200.1000327

Page 6 of 6

followed a top-down approach with a different degree. In all of the three regimes, university and State have always had unstable relationship. Though each supplies the other, their relations remain suspicious. On the one hand, the university contributes to the socio-economic and political development of the State by producing manpower while the State provides fund. On the other hand, the university, throughout the three regimes, has always been a source of resistance, protest, and even revolution and armed struggle. This is common to all the three regimes. As a response, all the three regimes have responded violently though with different degree (the imperial regime was less violent than the two regimes).

Thus, the paper has come up with the reasons that cause the relations between the university and the State uncertain and suspicious. This includes absence of institutional autonomy and academic freedom (the imperial regime had granted the university autonomy but suspended by the Derg, and the EPRDF regime have never grant autonomy till the enactment of the proclamation on Higher education institutions in 2003), State interference, State dominance of the administration of university and the political orientation of each regimes. This paper, therefore, calls that unless the top down model of relations between the university and the State is not revised, it would be the norm to have tense relations between them. Thus, it would be paramount to have a culture of interdependence in their future relations.

\section{References}

1. Eisemon TO, Salmi J (1993) African Universities and the State: Prospects for Reform in Senegal and Uganda. Higher Education 25: 151-168.

2. Thomas H (1967) African Universities and the State: Another View. Comparative Education 3: 107-114.

3. Addis Ababa University (2013) Student Handbook, Addis Ababa University.

4. Ahmed H (2006) Addis Ababa University Fifty-Three Years on an Insider's View. Cahiers d'Études Africaines 46: 291-312.

5. Randi Rønning B (2007) The quest for Expression: State and The University In Ethiopia Under Three Regimes, 952-2005. Addis Ababa: Addis Ababa University Press.

6. Habte A, Hewit MG, Kehoe M (1963) Higher Education in Ethiopia. Journal of Ethiopian Studies 1: 3-7.

7. Haile F (1984) A Study of Institutionality: Addis Ababa University 1961-1981. Dissertation, Indiana University, India.
8. Zewde B (2002) A History of Modern Ethiopia 1855-1991 (2ndedn), Addis Ababa: Addis Ababa University Press.

9. Arthur NG (1967) Higher Education in Ethiopia. Africa Today 14: 6-8.

10. Chro B (2009) Exploring the Concepts of Academic Freedom and Institutional Autonomy - A case study of the Faculty of Political Science at the University of Suleimaniyah. Unpublished Master thesis, Bergen University.

11. Harold GM (1994) A History of Ethiopia. California: University of California Press, Ltd.

12. Rønning RB (2009) Addis Ababa University in the Shadow of the Derg 1974 1991. In: Proceedings of the 16th International Conference of Ethiopian Studies.

13. Tola B (1997) To Kill a Generation: The Red Terror In Ethiopia. (2ndedn), Washington, D.C.: Free Ethiopia press.

14. John Y (1997) Peasant revolution in Ethiopia: The Tigray People's Liberation Front, New York: Cambridge University Press.

15. William S (2004) Higher Education in Ethiopia: The Vision and Its Challenges. Journal of Higher Education in Africa 2: 83-113.

16. Aredo D (2000) The Brain Drain from Ethiopia. Ethiopian Development Forum 1: $1-19$

17. Fabio B, Tjeldvoll A, Welle-Strand A (2005) The Complex Relations Between University, Society and State: The Ethiopian Predicament in Establishing Service University. Journal of Higher Education in Africa 3: 51-75.

18. David HS (2002) Reversing the Brain Drain In Ethiopia. Second Annual Conference of the Ethiopian North American Health Professionals Association (ENAHPA).

19. Human Rights Watch (2003) Ethiopia Lessons In Repression: Violations Of Academic Freedom In Ethiopia. 15: 1-52.

20. Hailu Y (2010) Governance in Ethiopian higher education system: State-higher Education institutions relationship, the case of Mekelle University. Unpublished Master Thesis, University of Tampere.

21. Federal Democratic Republic of Ethiopia (FDRE) (2009) Higher Education Proclamation No. 650/2009, Federal Negarit Gazeta, pp: 4976-5044.

22. Aschalew B (2011) The Path of Governance Transformation in Ethiopian Highe Education - Institutional Perspective, A Tale of Three Universities Experience with Respect to BPR Reform. Unpublished Thesis, Oslo University.

23. Saheed AA (2007) The History of Ethiopia. London: Greenwood Press.

24. Bishaw A, Lasser J (2012) Education in Ethiopia: Past, Present and Future Prospects, African Nebula, pp: 53-69.

25. World Bank (2003) Higher Education Development for Ethiopia: Pursuing the Vision. 